\title{
The Achievement Level of Vocational High School Students' Competency For The Competence Assessment in Bangkalan Regency
}

\author{
Mojibur Rohman \\ Graduate School of Vocational Education Program \\ Universitas Negeri Malang \\ Jl. Semarang 5 Malang - Indonesia \\ mujiburrohman1988@gmail.com
}

\begin{abstract}
Competence can be defined as one's ability to finish a certain task at work, and the person will receive an official certificate for this ability. Competence sets the specification of knowledge, skill, attitude and the implementation of the standard of work which is needed for a job. One of the ways which are used to determine the achievement level of the vocational high school students' competence is through students' competence assessment (Uji Kompetensi Siswa). This research aimed at determining the achievement level of students' competence in Bangkalan regency, especially from the department of Light Vehicle Engineering (TKR). This was a survey research with the descriptive qualitative approach. It involved 120 students who were the members of the population. The result of the research showed that generally the students' level of achievement reached $65 \%$ from the total population which was included as 'good' category.
\end{abstract}

\section{Keywords - students' competence, competence assessment}

\section{INTRODUCTION}

As a formal institution, Vocational High School $(S M K)$ is a secondary level of the education institution which aims to prepare the students to enter work field. The phenomenon in the field shows the existence of several problems that must be solved regarding the quality of education in $S M K$, where the graduates are still unemployed. In February 2017, Central Bureau of Statistics (BPS) noted that the graduates of $S M K$ are in the top rank with $9.27 \%$ for the number of the unemployment rate in Indonesia. It suggests that $S M K$ as an education institution must be able to equip the students with the skill and competence in accordance with the demand of the work field.

Competence is the ability to master certain task, skill, attitude and the appreciation which is needed to support the success [2]. It shows that competence covers task, skill, attitude, and appreciation that must be mastered by a student to carry out the learning tasks based on a specific work. Therefore, there will be a relationship between the tasks that students learn at school with the abilities needed in the work field.
The competency which must be mastered by the students has to be performed through a means so that it can be assessed, as the form of learning result in regards to the real experience of the students [3]. The students need to know the learning objectives and the achievement level that will be used as the criteria of explicit achievement, which is developed based on the objectives that have been set and have a contribution for the competencies that are being studied.

As a secondary school, SMK has an objective to provision the students with particular competence so they are ready for work field. The students will be categorized as competent if they have knowledge, skill, attitude and basic values to work. One of the ways to measure their level of competence is by conducting competence assessment or called as Ujian Kompetensi Siswa (UKK).

$U K K$ is a process to give recognition to the skill and authority of the students to run the particular task or work. The recognition of such expertise is done through the assessment of competence which refers to the standard of competence that is applicable and acknowledged in the work field. UKK is expected to ensure the implementation of competence-based assessment that is consistent and will encourage the learning process which is based on competence or production [4].

The implementation of $U K K$ is one of the evaluation processes which is conducted in grade XII to comprehend the extent of students' competence. It means that through $U K K$, the school can know whether a student is competent or not, in terms of theoretical or practical aspect. As it was mentioned before, the subjects of vocational skill's competence consist of theoretical test and vocational practice.

The test materials for $U K K$ are made by Board of National Education Standard $(B S N P)$. The materials of competence assessment are a test which is given for the competence from Light Vehicle Engineering (TKR) department and it comprises four types of tasks namely: (1) the tune-up of gasoline motor; (2) differential overhaul; (3) the maintenance of manual transmission system; and (4) the maintenance of electrical body. $U K K$ vocational practice is able to reflects holistically the level of students' competence after the learning process because it has six assessment components which are: (1) knowledge; (2) preparation; (3) process (procedure and style of work); (4) result of work; and (6) time [5]. 
This research was intended to know the achievement level of the students of $S M K$ during $U K K$, especially for Light Vehicle Engineering departments. The result of this study is expected to be used as the basic or consideration in making a decision to improve the quality of vocational school's graduates, particularly for the competence of Light Vehicle Engineering in Bangkalan regency.

\section{RESEARCH METHOD}

This research employed descriptive qualitative approach with the survey as the research type. Descriptive method was the method used to describe the current problems, aimed at describing things which should happen during the research. This research was taken place in Bangkalan regency, particularly in both public and private vocational schools in Light Vehicle Engineering department. The population in this research included 120 students from three schools as shown in Table 1.

TABLE I. DATA OF POPULATION DistRIBUTION

\begin{tabular}{clll}
\hline No. & \multicolumn{1}{c}{ Name of School } & \multicolumn{1}{c}{ Status } & Population \\
\hline 1. & SMK N 2 Bangkalan & State school & 61 students \\
2. & SMK Al Hikam & Private school & 41 students \\
3. & SMK N 1 Labang & State school & 18 students \\
& Total & & 120 \\
& & students \\
\hline
\end{tabular}

The sample is a part of number and characteristics which are owned by the population [6]. The bigger the number of sample (close to the number of population), so the opportunity of making mistakes for generalization is lower, and as a contrast, when the number of samples is a small sample (far from the number of population) so the bigger the chance of making a mistake for the generalization. According to the theory and the consideration of the population number, so this research took all the population's members as the sample of the research; or on the other hand, the sample of this research was population sample.

The technique for data collection in this research employed documentation by collecting the test result in competence assessment from the tree schools. In Table 2 presented below indicated the aspects of students' assessment in $U K K$.

TABLE II. VARIABLES OF THE RESEARCH AND DATA COLLECTION TECHNIQUE

\begin{tabular}{|c|c|c|c|}
\hline Variable & Sub-variable/ Indicator & $\begin{array}{c}\text { Data } \\
\text { Source }\end{array}$ & Technique \\
\hline $\begin{array}{l}\text { Student's } \\
\text { Com- } \\
\text { petence }\end{array}$ & $\begin{array}{l}\text { Knowledge } \\
\text { Preparation of work } \\
\text { Process (procedure \& } \\
\text { style of work) } \\
\text { Result of work } \\
\text { Attitude } \\
\text { Time }\end{array}$ & Student & $\begin{array}{l}\text { Documen- } \\
\text { tation }\end{array}$ \\
\hline
\end{tabular}

The data analysis in this research used descriptive statistic which was done with IBM SPSS version 24 program. The descriptive statistic reflects the collected data as it is by showing data that covers frequency distribution, total score, the average value of the score, standard deviation, mode, median, maximum score, a minimum score that is accompanied by car chart. Those data are described in the form of assessment's criteria [5].

\section{RESEARCH RESULT}

The data of the students' achievement level was obtained through documentation technique, by looking at the $U K K$ score of the students who became the sample of the research. To obtain those data, the researcher established cooperation with the stakeholders from the schools such as the head of the Automotive department and the teachers from productive subjects who handled $U K K$. Table 3 shows the data which have been collected and analyzed through descriptive analysis, while Table 4 shows the frequency distribution of the students' score.

TABLE III. THE STATISTICS OF UKK SCORE

\begin{tabular}{clc}
\hline No. & \multicolumn{1}{c}{ Statistik } & Nilai Statistik \\
\hline 1. & Number of respondents (N) & 120 \\
2. & Mean & 82,24 \\
3. & Median & 81,37 \\
4. & Mode & 80,03 \\
5. & Standard Deviation & 5,24 \\
6. & Variance & 27,96 \\
7. & Range & 34,87 \\
8. & Minimum Score & 59,03 \\
9. & Maximum Score & 93,90 \\
\hline
\end{tabular}

TABLE IV. FREQUENCY DISTRIBUTION OF UKK SCORE

\begin{tabular}{ccccc}
\hline No. & Classification & Frequency & $\begin{array}{c}\text { Percentage } \\
(\%)\end{array}$ & Category \\
\hline 1. & $59,00-67,70$ & 3 & $2,5 \%$ & $\mathrm{D}$ \\
2. & $67,80-76,50$ & 6 & $5,0 \%$ & $\mathrm{C}$ \\
3. & $76,60-85,30$ & 78 & $65,0 \%$ & $\mathrm{~B}$ \\
4. & $85,40-94,10$ & 33 & $27,5 \%$ & $\mathrm{~A}$ \\
\hline & TOTAL & $\mathbf{1 2 0}$ & $\mathbf{1 0 0} \%$ & \\
\hline
\end{tabular}

According to Table 4, it was known that the achievement of students' competence with poor category (D) was three students or $2.5 \%$ and the fair category was six students or $5 \%$. While 78 students, or $65 \%$, was categorized as good (B) and 33 students or $27.5 \%$ of the students got an excellent category. Thus, it was concluded that the students' competence in Bangkalan regency, particularly in Light Vehicle Engineering majorly was in a good category with $65 \%$ of the population. The achievement of the competence was assessed based on the students' ability to finish the tasks given in $U K K$ that comprised the aspects of knowledge, skill, and attitude. 


\section{DISCUSSION}

Vocational education is closely related to the concept of competence. Competence is seen as something that is related to the mastery of particular task, skill, attitude and appreciation which are owned by the students to finish the tasks related to certain work [2]. Since the curriculum of SMK has been developed and implemented with the approach of competence-based, so the system of learning as sessment must also in the form of competence-based assessment [4].

To know the achievement of students' competence, one of the ways is to go through assessment or test of work with practice-based. The performance test is done to measure students' competence in doing the tasks which are given based on the coverage of the materials from the competence [8]. On the other hand, the performance assessment is the appropriate way to be used for the education of technology and vocational study because there is an abundance of curriculum about technology and vocational study in the form of module and competency-based [9].

$U K K$ can be called as an assessment of work that can determine the assessment for the acquisition, the implementation of knowledge and skill, through the learning process that shows the students' ability in the process as well as the product. The assessment about the process and/or individual work is one of the characteristics in performance assessment, where every individual can show their ability optimally by their involvement in a process or in the resulting product [10]. As a result, it can be concluded that by $U K K$ implementation, the schools can measure and assess the level of competence from the students.

According to the research result shown in Table 3 and 4 , it could be seen that the achievement of SMK students' competence in Bangkalan regency especially in Light Vehicle Engineering reached the majority of 'good' category with $65 \%$ of the population whose average score was 82.24 . This result was obtained from the students' ability in completing the test was given, which comprised knowledge, skill and attitude aspects.

Competence refers to one's ability in completing the particular task in the work field and is proved by an official certificate for the skills. The competence sets the specification from knowledge, skill, attitude and the implementation of work standard that is needed at work [7]. A competent person in particular field is able to master the skills which are required for the job. In other words, that person can finish the tasks based on the working standard in the work field.

The graduated of $S M K$ must have the ability and skill in the form of competencies to do the work. The competence will help them to get a job when they graduate. Therefore, the implementation of education in $S M K$ especially in curriculum aspect must take a closer look at competence aspect which is targeted by the students. The content of the curriculum is selected and served with competency-based curriculum, broad-based curriculum), and life skill.

The competency-based learning approach is intended for the delivery of the learning materials to truly reflect the needs of the achievement of competence which is required for work. So as the planning of the learning implementation where the students are expected to obtain a learning experience which can develop their potential for the mastery through the stages of competencies which are learned. Even, conceptually, the learning process in $S M K$ is designed for direct working through the process of production as a means to study or called as production-based training.

The learning success of vocational study is highly determined by the quality of learning result itself. For increasing the quality of education, we need to pay attention to the quality of learning result and process to reach that objective [11]. It is also applied in $S M K$, to prepare human resources which are productive, independent and able to fill the demand of work market, the graduates as the prospective workers must muster not only hard skills but also soft skill [12].

\section{CONCLUSION AND RECCOMMENDATIONS}

Competence is the mastery of a task, skill, attitude and appreciation which are needed to support someone's success. $U K K$ is the process of learners' skill and authority acknowledgement in finishing the task or work. This skill's acknowledgement is made through a system of competence assessment which based on the standard of skill that is applied and accepted in the work field. According to the research result, the level of students' competence achievement for Light Vehicle Engineering department in Bangkalan regency, in average, was in 'good' category with $65 \%$ of the population and the average score of 82.24. To prepare the workers who are skillful and able to fill the demand from the industry, the graduates of the vocational school or $S M K$ must be competent, not only with hard skills but also soft skills.

\section{REFERENCES}

[1] Detik, "Banyak Lulusan SMK Jadi Pengangguran, Ini Penyebabnya". (Online), (https://finance.detik.com/berita-ekonomibisnis/3508298/banyak-Iulusan-smk-jadi-pengangguran-inipenyebabnya), accessed on September 8, 2017.

[2] Finch \& Crunkilton. 1999. Curriculum Development in Vocational and Technical Education Planing, Content, and Implementation (5thed). Bostom: Allyn and Bacom.

[3] Mulyasa, E. 2002. Manajemen Berbasis Sekolah. Bandung: PT Remaja Rosdakarya.

[4] Direktorat Pembinaan SMK. 2007.Petunjuk Teknis Penyelenggaraan Uji Kompetensi Keahlian Sekolah Menengah Kejuruan. Jakarta.

[5] Siswanto, Budi Tri. 2016. Faktor-Faktor Yang Mempengaruhi Hasil Belajar Siswa Pada Pembelajaran Praktik Kelistrikan Otomotif SMK Di Kota Yogyakarta. Jurnal Pendidikan Vokasi, 6 (1): 111-120. (Online) http://journal.uny.ac.id/index.php/jpv

[6] Sugiyono. 2011. Metode Penelitian Kuantitatif, Kualitatif, dan R\&D. Bandung: CV Alfabeta.

[7] Mulyasa, E. 2004. Kurikulum Berbasis Kompetensi, Konsep, Karakteristik dan Implementasi. Bandung: PT Remaja Rosdakarya.

[8] Suratno, Agus. 2016.Pengembangan Instrumen Penilaian Kompetensi Praktikum Engine Siswa SMK Program Keahlian Teknik Otomotif. Journal Of Mechanical Engineering Education, 1 (1): 1-11. (Online) http://jurnal.untirta.ac.id/index.php/vanos 
[9] Badmus, G., A. (2007). Changing nature of technical and vocational education and students' assessment methods. Nigeria: Department of Educational Psychology and Curriculum Studies University of Benin, Benin City.

[10] Airasian, P., W. (2001). Classroom assessment: Concepts and applications (4th ed.). Boston: McGraw-Hill.

[11] Zamroni. 2007. Meningkatkan Mutu Sekolah: Teori, Strategi, dan Prosedur. Jakarta: PSAP Muhammadiyah.

[12] Ihwanudin, M. 2016. Kontribusi Efikasi Diri Dan Keterampilan Belajar Terhadap Pencapaian Kompetensi TSM Siswa UPT-PK. Jurnal Pendidikan: Teori, Penelitian, dan Pengembangan. Volume: 1, Number: 11, November, 2016 